\title{
Influence of Seed Priming and Foliar Nutrition on Quality and Nutrient Uptake of Relay Grass Pea (Lathyrus sativus L.) in Gangetic Plains of West Bengal
}

\author{
Purabi Banerjee*, Bishal Mukherjee, Ananya Ghosh, \\ Madhushri Pramanik and Rajib Nath
}

\author{
Department of Agronomy, Bidhan Chandra Krishi Viswavidyalaya, \\ Mohanpur-741252, Nadia, West Bengal, India \\ *Corresponding author
}

\section{Keywords}

Foliar fertilization, Nutrient uptake, Quality, Relay grass pea, Seed priming

Article Info

Accepted:

23 April 2020

Available Online:

10 May 2020

\section{A B S T R A C T}

A field experiment was carried out at 'A-B' Block farm of BCKV, West Bengal, during subsequent winter seasons of 2017-18 and 2018-19 with grass pea variety Ratan (Bio L-212). Ten treatment combinations were laid out in a factorial RBD consisting seed priming with Ammonium molybdate @ $0.5 \mathrm{~g} \mathrm{~kg}^{-1}$ seed and foliar feeding at pre-flowering or a second spray at 15 days interval using $2 \%$ Urea or 0.5\% NPK (19:19:19) to analyse their effect on quality and nutrient uptake of relay grass pea. Priming coupled with twice foliar spray of Urea recorded highest $\mathrm{N}$ content in seed and stover and protein content (4.76, 0.98 and $29.77 \%$ respectively) followed by the combination of priming and twice foliar spray of NPK (19:19:19) with a non-significant interaction. The later attained highest yield $\left(1696.70 \mathrm{~kg} \mathrm{ha}^{-1}\right), \mathrm{P}$ and $\mathrm{K}$ content in seed $(0.39$ and $1.63 \%)$ and stover $(0.2$ and $1.1 \%$ ) along with maximum total $\mathrm{N}, \mathrm{P}$ and $\mathrm{K}$ uptakes $(108.21,17.07$ and $65.41 \mathrm{~kg}$ $\mathrm{ha}^{-1}$ ) respectively. So, seed priming combined with twice foliar spray of $0.5 \%$ NPK (19:19:19) might be recommended as a profitable technology for efficient production of relay grass pea with better quality and nutrient uptake under Gangetic plains of West Bengal.

\section{Introduction}

Grass pea (Lathyrus sativus L.) is a wonderful pulse for raising as relay crop under rice fallow situation (Bhowmick et al., 2014) with minimal external inputs (Nazrul and Shaheb, 2015). Due to its outstanding ability to withstand any kind of climatic adversities as well as poorly fertile soil, grass pea crop is an ideal legume for the resource-poor farmers (Dixit et al., 2016). This crop is booned with great nutritive values (Bhagat et al., 2015). The dried seeds of lathyrus contain 22.7-29.6 $\%$ unrefined protein, 56.6-61.0 \% carbohydrates, 0.6-1 g fat, 1.5-2.3 g fibre, 90$110 \mathrm{mg}$ calcium, $629 \mathrm{mg}$ potassium and 317- 
$500 \mathrm{mg}$ phosphorus, essential amino acids like arginine $(7.8 \mathrm{~g})$, lysine $(7.4 \mathrm{~g})$, isoleucine $(6.7 \mathrm{~g})$, leucine $(6.6 \mathrm{~g})$, valine $(4.7 \mathrm{~g})$ per 100 $\mathrm{g}$ of protein (Parihar and Gupta, 2016).

Molybdenum acts as a cofactor for nitrogenase and nitrate reductase enzymes (Togay et al., 2008), which are very essential for Rhizobium activity, nitrogen fixation, nitrate reduction, nitrogen transport and assimilation in legumes (Yadav et al., 2017). Seed priming of ammonium molybdate improves the yield by modulating morphophysiological characters and inhibiting flower and pod abscission.

Pulses under rainfed condition often experience nitrogen deficiency during reproductive stage because of the decline in biological nitrogen fixation owing to gradual degeneration of root nodules. Supplying supplementary $\mathrm{N}$ at this stage is effective in reducing flower and pod drop and thus enhancing growth and seed yield in legumes by instant availability of nitrogen (Bhowmick et al., 2013). Nitrogen plays an important role in biosynthesis of plant hormones like gibberelline, auxin and cytokinin through the action of different enzymes activity. Nitrogen fertilization increases the vegetative growth, total carbohydrate, soluble sugars and nutrients and protein contents of legumes. Foliar spray of $\mathrm{N}$ can delay the leaf senescence, thereby maintaining source to sink relation in legumes (Das and Jana, 2016). Phosphorus stimulates root, shoot, nodule, fruit and seed development as well as aids in vital metabolic functions like photosynthesis, carbon partitioning, sugar translocation, energy storage and transfer etc (Mmbaga et al., 2014). Besides, $\mathrm{P}$ provides energy in the form of ATP for effective nitrogenase activity and hence enhances rhizobial colonization and nitrogen fixation (Mitran et al., 2018). Adequate supply of potassium also enhances nitrogenase activity and nitrogen metabolism in legumes by accelerating ATP production to carry out biological nitrogen fixation in root nodules. Thus, K stimulates root and shoot growth, enhances and protein content of pulse grains (Srinivasarao, 2003). Besides, there is a well established role of $\mathrm{K}$ in regulating the water economy in plant body (Wang et al., 2013). The present experiment was planned to study the effect of seed priming with molybdenum coupled with foliar fertilization schedule with a view to improve the quality and nutrient uptake of relay grass pea.

\section{Materials and Methods}

The field experiment was conducted at District Seed Farm, 'A-B' block, (22 ${ }^{\circ} 93^{\prime} \mathrm{N}$ latitude, 88 $53^{\circ} \mathrm{E}$ longitude and $9.75 \mathrm{~m}$ above mean sea level) of Bidhan Chandra Krishi Viswavidyalaya, Kalyani, Nadia, West Bengal, India during two subsequent rabi seasons (October - March) of 2017-18 and 2018-19. The experimental soil was sandy loam in texture with $\mathrm{pH} 7.3$, EC $0.18 \mathrm{dS} \mathrm{m}^{-1}$, organic carbon $0.56 \%$, available $\mathrm{N} 231.28 \mathrm{~kg}$ $\mathrm{ha}^{-1}, \mathrm{P}_{2} \mathrm{O}_{5} 34.51 \mathrm{~kg} \mathrm{ha}^{-1}$, available $\mathrm{K}_{2} \mathrm{O} 188.83$ $\mathrm{kg} \mathrm{ha}{ }^{-1}$. The experiment was laid out in a factorial randomized block design replicated thrice comprising two seed priming levels viz. $\mathrm{S}_{1}$ : No seed priming and $\mathrm{S}_{2}$ : Seed priming with Ammonium molybdate @ $0.5 \mathrm{~g} \mathrm{~kg}^{-1}$ seed and five foliar spray levels viz. $\mathrm{F}_{1}$ : No foliar spray, $\mathrm{F}_{2}: 2 \%$ Urea spray at pre-flowering stage, $\mathrm{F}_{3}: 2 \%$ Urea spray at pre-flowering stage +15 days after $1^{\text {st }}$ spray, $\mathrm{F}_{4}: 0.5 \%$ NPK (19:19:19) spray at pre-flowering stage and $\mathrm{F}_{5}: 0.5 \%$ NPK $(19: 19: 19)$ spray at preflowering stage +15 days after $1^{\text {st }}$ spray. After being treated with Rhizobium biofertilizer@20 $\mathrm{g} \mathrm{kg}^{-1}$ of seed, grass pea [var. Ratan (Bio L-212)] seeds were broadcasted @ $80 \mathrm{~kg} \mathrm{ha}^{-1}$ on $2^{\text {nd }}$ and $3^{\text {rd }}$ week of October in the $1^{\text {st }}$ and $2^{\text {nd }}$ year respectively on standing rice [var. Satabdi (IET 4786)]. Rice crop was harvested after about a week from sowing of grass pea in the last week of 
October in both the years under investigation. Application of basal dose of fertilizers and irrigation were completely excluded for grass pea cultivation. The crop was harvested on $4^{\text {th }}$ week of February in both the years. Total rainfall receipts were 9.4 and $1.4 \mathrm{~mm}$ during the crop growth period in first and second year of experimentation respectively.

Plant samples were analyzed for N, P and K content. Samples were dried in an oven at $60^{\circ} \mathrm{C}$ till constant weight was obtained. The different plant parts viz. grain and stover were ground separately. The analysis was done by micro kjeldahl, Olsen's method and flame photometer for nitrogen, phosphorus and potassium respectively. The protein per cent in the seed was calculated by multiplying the nitrogen content by a factor of 6.25 .

Plant uptakes of $\mathrm{N}, \mathrm{P}$ or $\mathrm{K}$ was calculated separately by the following formula:

$$
\underset{\begin{array}{l}
\text { Uptake of } \mathrm{N} / \mathrm{P} / \mathrm{K} \\
\left(\mathrm{kg} \mathrm{ha}^{-1}\right)
\end{array}=}{\frac{\mathrm{N} \% / \mathrm{P} \% / \mathrm{K} \% \text { in seed or stover } \times \text { yield }\left(\mathrm{kg} \mathrm{ha}^{-1}\right)}{100}}
$$

Individual total uptakes of $\mathrm{N}, \mathrm{P}$ and $\mathrm{K}$ in plant were calculated by addition of the uptake of respective nutrients in seed and stover.

\section{Results and Discussion}

\section{Nutrients content (\%) in lathyrus}

Pooled analysis in Table 1 revealed that the treatment of seed priming with Ammonium molybdate coupled with twice foliar spray of $2 \%$ urea $\left(\mathrm{S}_{2} \mathrm{~F}_{3}\right)$ contained maximum $\mathrm{N}$ in seed $(4.76 \%)$ and in stover $(0.98 \%)$ followed by $\mathrm{S}_{2} \mathrm{~F}_{5}$ (4.65 and $0.93 \%$ respectively). Highest $\mathrm{P}$ and $\mathrm{K}$ contents were observed with treatment $\mathrm{S}_{2} \mathrm{~F}_{5}$ i.e., seed priming with Ammonium molybdate coupled with twice foliar spray of $0.5 \% \mathrm{NPK}(19: 19: 19)$ in both seed $(0.39$ and $1.63 \%)$ and stover $(0.29$ and $1.19 \%$ ) respectively (Table 2 and 3 ).

Literatures exhibited improvement of nutrient contents through seed priming with molybdenum in legume crops like chickpea (Gupta and Gangwar, 2012), lentil (Togay et al., 2008), mungbean (Samant, 2017), peanut (Mandou et al., 2017) etc. Improvement of nitrogen content in crops through foliar feeding of urea could be explained by the theory of Yildirim et al., (2007). They stated that the absorption of urea by the leaves was higher and faster than that of inorganic nitrogen forms because of the better permeability of urea to cuticular membrane than to inorganic ions (10 to 20 times more). Similar findings were reported by Venkatesh and Basu (2011) in chickpea.

\section{Protein content $(\%)$ in lathyrus}

Treatment $\mathrm{S}_{2} \mathrm{~F}_{3}$ yielded highest amount of protein content in grass pea seeds $(29.77 \%)$ followed by $\mathrm{S}_{2} \mathrm{~F}_{5}(29.03 \%)$ which were about 24.2 and $21.11 \%$ greater than control (Table 4). Foliar application of nutrients specially nitrogen might have positively influenced carbohydrate and protein synthesis.

Tahir et al., (2011) reported increased seed protein content in mungbean through combined application of Mo $4 \mathrm{~g} \mathrm{~kg}^{-1}$ seed + Rhizobium inoculation. Positive effects of foliar feeding of urea on yield and seed protein contents of chickpea (Palta et al., 2005; Bahr, 2007) and lentil (Das and Jana, 2016) have been reported earlier. 


\begin{tabular}{|c|c|c|c|c|c|c|}
\hline \multirow[t]{2}{*}{ Treatment } & \multicolumn{3}{|c|}{ Seed N (\%) } & \multicolumn{3}{|c|}{ Stover N (\%) } \\
\hline & 2017-18 & 2018-19 & Pooled & 2017-18 & 2018-19 & Pooled \\
\hline $\mathbf{S}_{1} \mathbf{F}_{1}$ & 3.98 & 3.68 & 3.83 & 0.62 & 0.61 & 0.61 \\
\hline $\mathbf{S}_{1} \mathbf{F}_{2}$ & 4.23 & 4.10 & 4.17 & 0.80 & 0.81 & 0.81 \\
\hline $\mathbf{S}_{1} \mathbf{F}_{3}$ & 4.66 & 4.32 & 4.49 & 0.87 & 0.87 & 0.87 \\
\hline $\mathbf{S}_{1} \mathbf{F}_{4}$ & 4.15 & 4.03 & 4.09 & 0.75 & 0.76 & 0.76 \\
\hline $\mathbf{S}_{1} \mathbf{F}_{5}$ & 4.54 & 4.21 & 4.38 & 0.82 & 0.83 & 0.83 \\
\hline $\mathbf{S}_{2} \mathbf{F}_{1}$ & 4.05 & 4.06 & 4.06 & 0.70 & 0.67 & 0.69 \\
\hline $\mathbf{S}_{2} \mathbf{F}_{2}$ & 4.48 & 4.31 & 4.40 & 0.87 & 0.87 & 0.87 \\
\hline $\mathbf{S}_{2} \mathbf{F}_{3}$ & 4.87 & 4.66 & 4.76 & 0.98 & 0.99 & 0.98 \\
\hline $\mathbf{S}_{2} \mathbf{F}_{4}$ & 4.41 & 4.23 & 4.32 & 0.84 & 0.82 & 0.83 \\
\hline $\mathbf{S}_{2} \mathbf{F}_{5}$ & 4.76 & 4.53 & 4.65 & 0.92 & 0.93 & 0.93 \\
\hline $\operatorname{S.Em}( \pm)$ & 0.06 & 0.06 & 0.05 & 0.01 & 0.01 & 0.01 \\
\hline C.D. $(P=0.05)$ & NS & NS & NS & NS & NS & NS \\
\hline
\end{tabular}

\begin{tabular}{|c|c|c|c|c|c|c|}
\hline \multirow[t]{2}{*}{ Treatment } & \multicolumn{3}{|c|}{ Seed P $(\%)$} & \multicolumn{3}{|c|}{ Stover P $(\%)$} \\
\hline & 2017-18 & 2018-19 & Pooled & 2017-18 & 2018-19 & Pooled \\
\hline $\mathbf{S}_{\mathbf{1}} \mathbf{F}_{1}$ & 0.28 & 0.26 & 0.27 & 0.15 & 0.15 & 0.18 \\
\hline $\mathbf{S}_{1} \mathbf{F}_{2}$ & 0.32 & 0.30 & 0.31 & 0.19 & 0.19 & 0.22 \\
\hline $\mathbf{S}_{\mathbf{1}} \mathbf{F}_{3}$ & 0.34 & 0.32 & 0.33 & 0.22 & 0.23 & 0.25 \\
\hline $\mathbf{S}_{1} \mathbf{F}_{4}$ & 0.37 & 0.36 & 0.36 & 0.25 & 0.26 & 0.27 \\
\hline $\mathbf{S}_{1} \mathbf{F}_{5}$ & 0.40 & 0.39 & 0.39 & 0.28 & 0.29 & 0.31 \\
\hline $\mathbf{S}_{2} \mathbf{F}_{1}$ & 0.31 & 0.29 & 0.27 & 0.19 & 0.17 & 0.15 \\
\hline $\mathbf{S}_{2} \mathbf{F}_{2}$ & 0.35 & 0.32 & 0.31 & 0.22 & 0.22 & 0.19 \\
\hline $\mathbf{S}_{2} \mathbf{F}_{3}$ & 0.37 & 0.34 & 0.33 & 0.25 & 0.25 & 0.23 \\
\hline $\mathbf{S}_{2} \mathbf{F}_{4}$ & 0.41 & 0.38 & 0.36 & 0.27 & 0.28 & 0.26 \\
\hline $\mathbf{S}_{2} \mathbf{F}_{5}$ & 0.43 & 0.42 & 0.39 & 0.30 & 0.32 & 0.29 \\
\hline $\operatorname{S.Em}( \pm)$ & 0.01 & 0.01 & 0.01 & 0.01 & 0.01 & 0.003 \\
\hline C.D. $(P=0.05)$ & NS & NS & NS & NS & NS & NS \\
\hline
\end{tabular}




\begin{tabular}{|c|c|c|c|c|c|c|}
\hline Table.3 Effect of seed priming and foliar sprays on potassium content of grass pea \\
\hline Treatment & \multicolumn{3}{|c|}{ Seed K (\%) } & \multicolumn{3}{c|}{ Stover K (\%) } \\
\hline & $\mathbf{2 0 1 7 - 1 8}$ & $\mathbf{2 0 1 8 - 1 9}$ & Pooled & $\mathbf{2 0 1 7 - 1 8}$ & $\mathbf{2 0 1 8}-19$ & Pooled \\
\hline $\mathbf{S}_{\mathbf{1}} \mathbf{F}_{\mathbf{1}}$ & 1.22 & 1.24 & 1.23 & 0.97 & 0.99 & 0.98 \\
\hline $\mathbf{S}_{\mathbf{1}} \mathbf{F}_{\mathbf{2}}$ & 1.34 & 1.35 & 1.35 & 1.03 & 1.04 & 1.04 \\
\hline $\mathbf{S}_{\mathbf{1}} \mathbf{F}_{\mathbf{3}}$ & 1.44 & 1.44 & 1.44 & 1.09 & 1.07 & 1.08 \\
\hline $\mathbf{S}_{\mathbf{1}} \mathbf{F}_{\mathbf{4}}$ & 1.50 & 1.50 & 1.50 & 1.12 & 1.10 & 1.11 \\
\hline $\mathbf{S}_{\mathbf{1}} \mathbf{F}_{\mathbf{5}}$ & 1.57 & 1.57 & 1.57 & 1.15 & 1.14 & 1.14 \\
\hline $\mathbf{S}_{\mathbf{2}} \mathbf{F}_{\mathbf{1}}$ & 1.30 & 1.31 & 1.30 & 1.00 & 1.02 & 1.01 \\
\hline $\mathbf{S}_{\mathbf{2}} \mathbf{F}_{\mathbf{2}}$ & 1.42 & 1.43 & 1.43 & 1.08 & 1.07 & 1.07 \\
\hline $\mathbf{S}_{\mathbf{2}} \mathbf{F}_{\mathbf{3}}$ & 1.48 & 1.48 & 1.48 & 1.12 & 1.14 & 1.13 \\
\hline $\mathbf{S}_{\mathbf{2}} \mathbf{F}_{\mathbf{4}}$ & 1.55 & 1.56 & 1.56 & 1.13 & 1.17 & 1.15 \\
\hline $\mathbf{S}_{\mathbf{2}} \mathbf{F}_{\mathbf{5}}$ & 1.63 & 1.63 & 1.63 & 1.18 & 1.20 & 1.19 \\
\hline $\mathbf{S . E m} \mathbf{E} \mathbf{+}$ & $\mathbf{0 . 0 1}$ & $\mathbf{0 . 0 1}$ & $\mathbf{0 . 0 5}$ & $\mathbf{0 . 0 1}$ & $\mathbf{0 . 0 1}$ & $\mathbf{0 . 0 1}$ \\
\hline $\mathbf{C . D .}(\mathbf{P}=\mathbf{0 . 0 5})$ & $\mathbf{N S}$ & $\mathbf{N S}$ & $\mathbf{N S}$ & $\mathbf{N S}$ & $\mathbf{0 . 0 2}$ & $\mathbf{N S}$ \\
\hline
\end{tabular}

\begin{tabular}{|c|c|c|c|}
\hline \multicolumn{2}{|c|}{ Table.4 Effect of seed priming and foliar sprays on protein content of grass pea } \\
\hline \multirow{2}{*}{ Treatment } & \multicolumn{3}{|c|}{ Seed protein (\%) } \\
\hline & $\mathbf{2 0 1 7 - 1 8}$ & $\mathbf{2 0 1 8 - 1 9}$ & Pooled \\
\hline $\mathbf{S}_{\mathbf{1}} \mathbf{F}_{\mathbf{1}}$ & 24.92 & 23.02 & 23.97 \\
\hline $\mathbf{S}_{\mathbf{1}} \mathbf{F}_{\mathbf{2}}$ & 26.46 & 25.65 & 26.05 \\
\hline $\mathbf{S}_{\mathbf{1}} \mathbf{F}_{\mathbf{3}}$ & 29.15 & 27.01 & 28.08 \\
\hline $\mathbf{S}_{\mathbf{1}} \mathbf{F}_{\mathbf{4}}$ & 25.92 & 25.21 & 25.57 \\
\hline $\mathbf{S}_{\mathbf{1}} \mathbf{F}_{\mathbf{5}}$ & 28.38 & 26.33 & 27.35 \\
\hline $\mathbf{S}_{\mathbf{2}} \mathbf{F}_{\mathbf{1}}$ & 25.33 & 25.38 & 25.35 \\
\hline $\mathbf{S}_{\mathbf{2}} \mathbf{F}_{\mathbf{2}}$ & 27.98 & 26.97 & 27.47 \\
\hline $\mathbf{S}_{\mathbf{2}} \mathbf{F}_{\mathbf{3}}$ & 30.44 & 29.10 & 29.77 \\
\hline $\mathbf{S}_{\mathbf{2}} \mathbf{F}_{\mathbf{4}}$ & 27.54 & 26.41 & 26.98 \\
\hline $\mathbf{S}_{\mathbf{2}} \mathbf{F}_{\mathbf{5}}$ & 29.75 & 28.31 & 29.03 \\
\hline $\mathbf{S . E m} \mathbf{(} \mathbf{(}$ & $\mathbf{0 . 3 7}$ & $\mathbf{0 . 3 7}$ & $\mathbf{0 . 2 9}$ \\
\hline $\mathbf{C . D} .(\mathbf{P}=\mathbf{0 . 0 5})$ & $\mathbf{N S}$ & $\mathbf{N S}$ & $\mathbf{N S}$ \\
\hline & & & \\
\hline
\end{tabular}




\begin{tabular}{|c|c|c|c|c|c|c|c|c|c|}
\hline \multirow[t]{2}{*}{ Treatment } & \multicolumn{3}{|c|}{ Seed N uptake (kg/ha) } & \multicolumn{3}{|c|}{ Stover N uptake (kg/ha) } & \multicolumn{3}{|c|}{ Total uptake of $\mathrm{N}(\mathrm{kg} / \mathrm{ha})$} \\
\hline & 2017-18 & 2018-19 & Pooled & 2017-18 & 2018-19 & Pooled & 2017-18 & 2018-19 & Pooled \\
\hline $\mathbf{S}_{1} \mathbf{F}_{1}$ & 42.08 & 41.01 & 41.55 & 16.31 & 15.23 & 15.77 & 58.39 & 56.23 & 57.31 \\
\hline $\mathbf{S}_{1} \mathbf{F}_{2}$ & 56.89 & 51.64 & 54.26 & 22.42 & 21.13 & 21.77 & 79.31 & 72.76 & 76.04 \\
\hline $\mathbf{S}_{1} \mathbf{F}_{3}$ & 65.29 & 59.33 & 62.31 & 24.66 & 23.42 & 24.04 & 89.95 & 82.74 & 86.35 \\
\hline $\mathbf{S}_{1} \mathbf{F}_{4}$ & 61.42 & 53.23 & 57.32 & 22.84 & 20.14 & 21.49 & 84.26 & 73.38 & 78.82 \\
\hline $\mathbf{S}_{1} \mathbf{F}_{5}$ & 70.92 & 59.08 & 65.00 & 25.83 & 22.53 & 24.18 & 96.75 & 81.61 & 89.18 \\
\hline $\mathbf{S}_{2} \mathbf{F}_{1}$ & 49.76 & 46.50 & 48.13 & 19.98 & 17.33 & 18.65 & 69.74 & 63.83 & 66.78 \\
\hline $\mathbf{S}_{2} \mathbf{F}_{2}$ & 66.58 & 60.60 & 63.59 & 25.86 & 23.28 & 24.57 & 92.44 & 83.87 & 88.16 \\
\hline $\mathbf{S}_{2} \mathbf{F}_{3}$ & 75.43 & 69.04 & 72.23 & 29.73 & 27.23 & 28.48 & 105.16 & 96.26 & 100.71 \\
\hline $\mathbf{S}_{2} \mathbf{F}_{4}$ & 72.18 & 65.84 & 69.01 & 27.38 & 23.87 & 25.63 & 99.56 & 89.71 & 94.63 \\
\hline $\mathbf{S}_{2} \mathbf{F}_{5}$ & 82.20 & 75.50 & 78.85 & 30.95 & 27.77 & 29.36 & 113.14 & 103.27 & 108.21 \\
\hline $\operatorname{S.Em}( \pm)$ & 0.98 & 0.73 & 0.65 & 0.32 & 0.42 & 0.31 & 0.89 & 0.84 & 0.62 \\
\hline C.D. $(P=0.05)$ & NS & 2.17 & 1.96 & NS & 1.25 & 0.93 & NS & 2.50 & 1.86 \\
\hline
\end{tabular}

\begin{tabular}{|c|c|c|c|c|c|c|c|c|c|}
\hline \multirow[t]{2}{*}{ Treatment } & \multicolumn{3}{|c|}{ Seed P uptake (kg/ha) } & \multicolumn{3}{|c|}{ Stover $P$ uptake $(\mathrm{kg} / \mathrm{ha})$} & \multicolumn{3}{|c|}{ Total uptake of $P(\mathrm{~kg} / \mathrm{ha})$} \\
\hline & 2017-18 & 2018-19 & Pooled & 2017-18 & 2018-19 & Pooled & 2017-18 & 2018-19 & Pooled \\
\hline $\mathbf{S}_{1} \mathbf{F}_{1}$ & 4.13 & 3.03 & 3.19 & 3.97 & 3.74 & 3.85 & 7.33 & 6.77 & 7.05 \\
\hline $\mathbf{S}_{1} \mathbf{F}_{2}$ & 5.16 & 3.73 & 4.02 & 5.30 & 4.95 & 5.13 & 9.60 & 8.69 & 9.14 \\
\hline $\mathbf{S}_{1} \mathbf{F}_{3}$ & 5.68 & 4.44 & 4.60 & 6.36 & 6.10 & 6.23 & 11.13 & 10.54 & 10.83 \\
\hline $\mathbf{S}_{1} \mathbf{F}_{4}$ & 6.77 & 4.71 & 5.07 & 7.68 & 6.89 & 7.29 & 13.11 & 11.59 & 12.35 \\
\hline $\mathbf{S}_{1} \mathbf{F}_{5}$ & 7.48 & 5.47 & 5.83 & 8.68 & 7.93 & 8.31 & 14.88 & 13.40 & 14.14 \\
\hline $\mathbf{S}_{2} \mathbf{F}_{1}$ & 3.36 & 3.61 & 3.87 & 5.30 & 4.46 & 4.88 & 9.44 & 8.06 & 8.75 \\
\hline $\mathbf{S}_{2} \mathbf{F}_{2}$ & 4.30 & 4.45 & 4.80 & 6.46 & 6.00 & 6.23 & 11.62 & 10.44 & 11.03 \\
\hline $\mathbf{S}_{2} \mathbf{F}_{3}$ & 4.76 & 5.04 & 5.36 & 7.61 & 6.87 & 7.24 & 13.29 & 11.92 & 12.60 \\
\hline $\mathbf{S}_{2} \mathbf{F}_{4}$ & 5.43 & 5.97 & 6.37 & 8.77 & 8.09 & 8.43 & 15.54 & 14.06 & 14.80 \\
\hline $\mathbf{S}_{2} \mathbf{F}_{5}$ & 6.20 & 7.00 & 7.24 & 10.17 & 9.49 & 9.83 & 17.65 & 16.49 & 17.07 \\
\hline $\operatorname{S.Em}( \pm)$ & 0.11 & 0.09 & 0.07 & 0.21 & 0.14 & 0.11 & 0.20 & 0.17 & 0.12 \\
\hline C.D. $(\mathbf{P}=\mathbf{0 . 0 5})$ & 0.32 & 0.28 & 0.22 & NS & NS & NS & NS & 0.51 & 0.37 \\
\hline
\end{tabular}




\begin{tabular}{|c|c|c|c|c|c|c|c|c|c|}
\hline \multirow[t]{2}{*}{ Treatment } & \multicolumn{3}{|c|}{ Seed K uptake (kg ha $\left.{ }^{-1}\right)$} & \multicolumn{3}{|c|}{ Stover K uptake (kg ha $\left.{ }^{-1}\right)$} & \multicolumn{3}{|c|}{ Total uptake of $\mathrm{K}\left(\mathrm{kg} \mathrm{ha}^{-1}\right)$} \\
\hline & 2017-18 & 2018-19 & Pooled & 2017-18 & 2018-19 & Pooled & 2017-18 & 2018-19 & Pooled \\
\hline $\mathbf{S}_{1} \mathbf{F}_{1}$ & 14.60 & 14.40 & 14.50 & 25.57 & 24.63 & 25.10 & 40.17 & 39.02 & 39.59 \\
\hline $\mathbf{S}_{1} \mathbf{F}_{2}$ & 17.96 & 17.03 & 17.50 & 28.74 & 27.22 & 27.98 & 46.71 & 44.25 & 45.48 \\
\hline $\mathbf{S}_{1} \mathbf{F}_{3}$ & 20.16 & 19.72 & 19.94 & 30.94 & 28.79 & 29.87 & 51.11 & 48.52 & 49.81 \\
\hline $\mathbf{S}_{1} \mathbf{F}_{4}$ & 22.27 & 19.80 & 21.03 & 33.86 & 29.15 & 31.50 & 56.13 & 48.94 & 52.53 \\
\hline $\mathbf{S}_{1} \mathbf{F}_{5}$ & 24.57 & 22.06 & 23.32 & 35.97 & 30.73 & 33.35 & 60.55 & 52.79 & 56.67 \\
\hline $\mathbf{S}_{2} \mathbf{F}_{1}$ & 17.33 & 16.25 & 16.79 & 28.31 & 26.33 & 27.32 & 45.63 & 42.58 & 44.11 \\
\hline $\mathbf{S}_{2} \mathbf{F}_{2}$ & 21.12 & 20.09 & 20.60 & 32.22 & 28.65 & 30.44 & 53.34 & 48.74 & 51.04 \\
\hline $\mathbf{S}_{2} \mathbf{F}_{3}$ & 22.93 & 21.90 & 22.41 & 34.19 & 31.26 & 32.73 & 57.12 & 53.16 & 55.14 \\
\hline $\mathbf{S}_{2} \mathbf{F}_{4}$ & 25.39 & 24.30 & 24.85 & 36.80 & 34.09 & 35.45 & 62.19 & 58.40 & 60.30 \\
\hline $\mathbf{S}_{2} \mathbf{F}_{5}$ & 28.09 & 27.22 & 27.65 & 39.66 & 35.86 & 37.76 & 67.75 & 63.08 & 65.41 \\
\hline S.Em( $( \pm)$ & 0.22 & 0.21 & 0.16 & 0.31 & 0.32 & 0.24 & 0.41 & 0.47 & 0.34 \\
\hline C.D. $(P=0.05)$ & NS & 0.63 & 0.49 & NS & 0.95 & 0.73 & NS & 1.40 & 1.01 \\
\hline
\end{tabular}

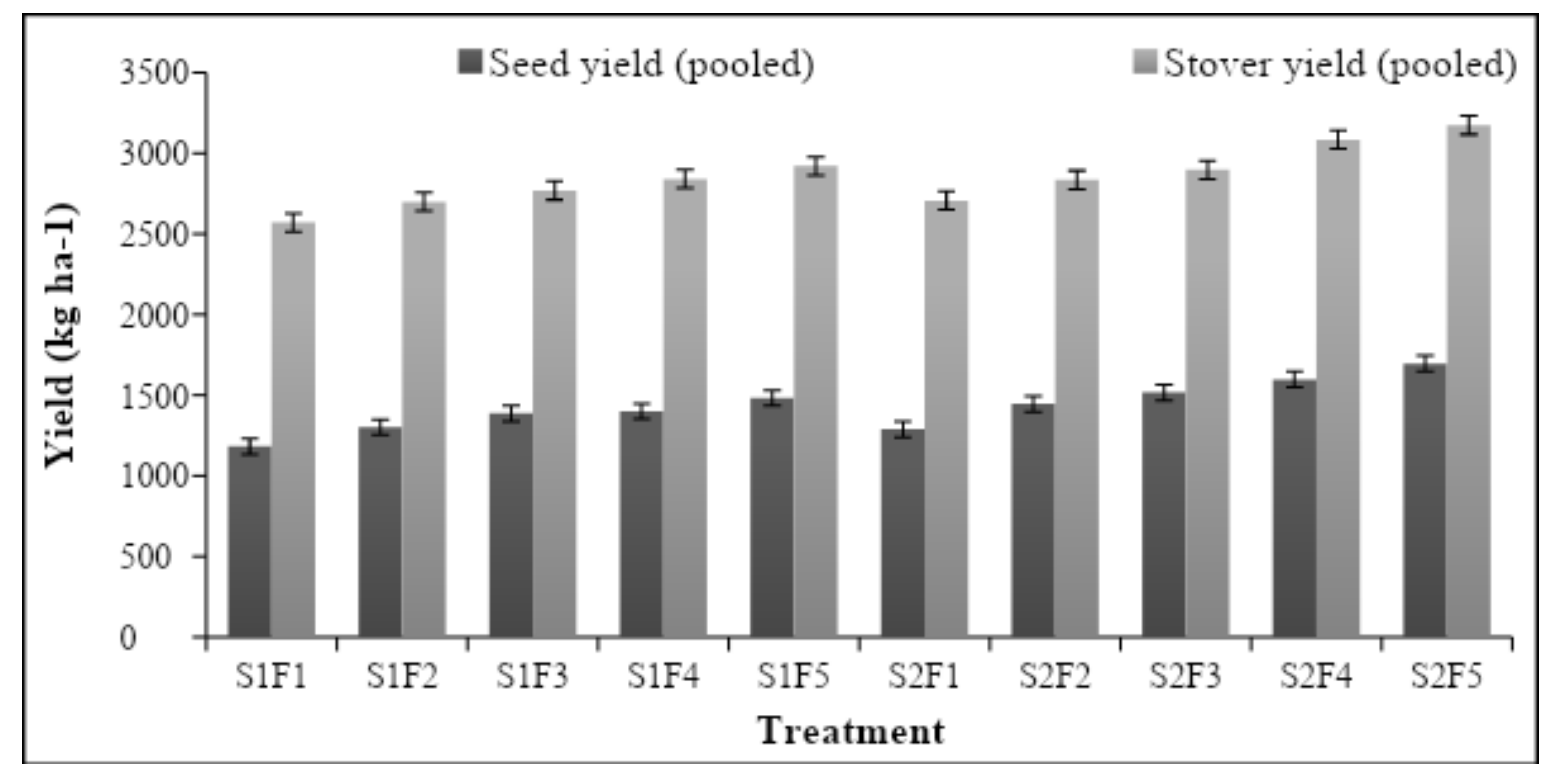

Nutrients uptake $\left(\mathrm{kg} \mathrm{ha}^{-1}\right)$ in lathyrus

Seed priming and foliar nutrient sprays played important role to create significant variations in uptakes of nitrogen, phosphorus and potassium in the plant parts during both the years under experimentation as well as in their pooled results. Treatment $\mathrm{S}_{2} \mathrm{~F}_{5}$ was registered for maximum uptake of $\mathrm{N}, \mathrm{P}$ and $\mathrm{K}$ in seed $\left(78.85,7.24\right.$ and $\left.27.65 \mathrm{~kg} \mathrm{ha}^{-1}\right)$ and stover (29.36, 9.83 and $37.76 \mathrm{~kg} \mathrm{ha}^{-1}$ ) along with total uptake $(108.21,17.07$ and $65.41 \mathrm{~kg}$ $\mathrm{ha}^{-1}$ ) in grass pea as per pooled estimation, all being statistically significant over control (Table 5, 6 and 7). Maximum uptake of all nutrients in seed, stover as well as in total was 
obtained with application of seed priming with Ammonium molybdate @ $0.5 \mathrm{~g} \mathrm{~kg}^{-1}$ seed followed by $0.5 \%$ NPK $(19: 19: 19)$ spray at pre-flowering and 15 days after 1st spray in relay grass pea because of highest yield in that particular treatment (Figure 1).

Maximum uptake of $\mathrm{P}$ and $\mathrm{K}$ in the same treatment might be due to the combined effect of highest $\mathrm{P}$ and $\mathrm{K}$ content along with maximum yield in that plot. Navaz et al., (2018) reported that seed priming with Sodium molybdate @ $0.5 \mathrm{~g} \mathrm{~kg}^{-1}$ seed combined with $0.5 \%$ foliar spray of NPK 19:19:19 at pre-flowering and 15 days after the $1^{\text {st }}$ spray recorded maximum uptake of $\mathrm{P}$ in seeds and stover as well as in total. Likewise, Gowda et al., (2015) reported that foliar spray of 19:19:19 @ 0.4\% in pigeon pea led to significant higher uptake of nitrogen, phosphorus and potassium.

From the above findings, it can be concluded that an affordable combination of seed priming with Ammonium molybdate @ $0.5 \mathrm{~g}$ $\mathrm{kg}^{-1}$ seed along with foliar spray of $0.5 \%$ NPK (19:19:19) at pre-flowering stage and 15 days after the $1^{\text {st }}$ spray may be recommended for efficient production of relay grass pea [var. Ratan (Bio L-212)] with better quality and nutrient uptake under rice fallow situation in Gangetic plains of West Bengal.

\section{References}

Bahr, A.A. (2007). Effect of plant density and urea foliar application on yield and yield components of chickpea (Cicer arietinum). Research Journal of Agriculture and Biological Sciences, 3(4): 220-223.

Bhagat, G.J., Kamdi, S.R., Neharkar, P.S., Ghate, S.R. and Kadu, P.R. (2015). Influence of integrated nutrient management on paddylathyrus cropping system in eastern Vidarbha region. International Journal of Tropical Agriculture. 4(2): 16-20.

Bhowmick, M.K., Duary, B., Biswas, P. K., Rakshit, A. and Adhikari, B. (2013). Seed priming, row spacing and foliar nutrition in relation to growth and yield of chickpea under rainfed condition. SATSA Mukhapatra - Annual Technical Issue, 17: 114-119.

Bhowmick, M.K., Dhara, M.C. Duary, B., Biswas, P.K. and Bhattacharyya, P. (2014). Improvement of lathyrus productivity through seed priming and foliar nutrition under rice-utera system. Journal of Crop and Weed, 10(2):277-280.

Das, S.K. and Jana. K. (2016). Effect of seed hydro-priming and urea spray on yield parameters, yield and quality of lentil (Lens culinaris Medikus). Legume Research, 39(5): 830-833.

Dixit, G.P., Parihar, A.K., Bohra, A. and Singh, N.P. (2016). Achievements and prospects of grass pea (Lathyrus sativus L.) improvement for sustainable food production. The Crop Journal, 4: 407- 416.

Gowda, K.M., Halepyati, A.S., Koppalkar, B.G. and Rao, S. (2015). Yield, nutrient uptake and economics of pigeonpea (Cajanus cajan L. Millsp.) as influenced by soil application of micronutrients and foliar spray of macronutrients. Karnataka Journal of Agricultural Sciences, 28(2): 266-268.

Gupta, S.C. and Gangwar, S. (2012). Effect of molybdenum, iron and microbial inoculants on symbiotic traits, nutrient uptake and yield of chickpea. Journal of Food Legumes, 25(1): 45-49.

Mandou, M.S., Chotangui, A.H., Nkot, L.N. and Nwaga, D. (2017). Effect of Rhizobia inoculation phosphorus and molybdenum application on nodulation, $\mathrm{N}$ uptake and yield of peanut (Arachis hypogaea L.). International Journal of Agronomy and Agricultural Research, 11(1): 103-113.

Mitran, T., Meena, R.S., Lal, R., Layek, J., Kumar, S. and Datta, R. 2018. Role of Soil Phosphorus on Legume Production. In: Meena R., Das A., Yadav G., Lal R. (eds) Legumes for Soil Health and Sustainable Management. Springer, Singapore. Pp: 487510.

Mmbaga, G.W., Mtei, K.M. and Ndakidemi, P.A. (2014). Extrapolations on the use of Rhizobium inoculants supplemented with phosphorus $(\mathrm{P})$ and potassium $(\mathrm{K})$ on 
growth and nutrition of legumes. Journal of Agricultural Science, 5: 1207-1226.

Navaz, M., Kumar, S., Shrivastava,G.K., Mandavi, M., Salam, P.K. and Pandey, N. (2018). Impact of foliar spray of nutrients and seed treatment on uptake of phosphorus of plant and seed of lathyrus (Lathyrus sativus L.) Under relay cropping system. International Journal of Fauna and Biological Studies, 5(2): 01-02.

Nazrul, M.I. and Shaheb, M.S. (2015). Adaptation of grass pea as sole and relay cropping systems with transplanted aman rice in Sylhet region of Bangladesh. American Journal of Biology and Life Sciences, 3(6): 254-259.

Palta, J.A., Nandwal, A.S., Kumari, S., Turner, N.C. (2005). Foliar nitrogen applications increase the seed yield and protein content in chickpea (Cicer arietinum L.) subject to terminal drought. Australian Journal of Agricultural Research, 56: 105-112.

Parihar, A.K. and Gupta, S. (2016). In: Lathyrus cultivation in India (pocket guide). Technical Bulletin. Published by Project Coordinator, AICRP on MULLaRP, ICARIIPR, Kanpur 208024. pp. 1-7.

Pederson, G.A., Brink, G.E. and Fairbrother, T.E. (2002). Nutrient uptake in plant parts of sixteen forages fertilized with poultry litter: nitrogen, phosphorus, potassium, copper, and zinc. Agronomy Journal, 94: 895-904.

Samant, T.K. (2017) Effect of Rhizobium and molybdenum inoculation on yield, economics, nodulation and nitrogen uptake in mungbean (Vigna radiata L.). International Journal of Chemical Studies, 5(5): 1376-1379.
Srinivasarao, C., Ali, M., Ganeshamurthy, A.N. and Singh, K.K. (2003). Potassium requirements of pulse crops. Better Crops International, 17(1): 9-11.

Tahir, M., Ali, A., Aabidin, N., Yaseen, M. and Rehman, H. (2011). Effect of molybdenum and seed inoculation on growth, yield and quality of mungbean. Crop \& Environment, 2(2): 37-40.

Togay, Y., Togay, N. and Dogan, Y. (2008). Research on the effect of phosphorus and molybdenum applications on the yield and yield parameters in lentil (Lens culinaris Medic.). African Journal of Biotechnology, 7(9): 1256-1260.

Venkatesh, M.S. and Basu, P.S. (2011). Effect of foliar application of urea on growth, yield and quality of chickpea under rainfed conditions. Journal of Food Legumes, 24(2): 110-112.

Wang, M., Zheng, Q., Shen, Q. and Guo, S. (2013) The critical role of potassium in plant stress response. International Journal of Molecular Sciences, 14: 7370-7390.

Yadav, A., Yadav, L.R. and Yadav, S.S. (2017). Effect of molybdenum on nodulation, total nutrient uptake and protein content of clusterbean [Cyamopsis tetragonoloba (L.) Taub] varieties. International Journal of Current Microbiology and Applied Sciences, 6(5): 1939-1944.

Yildirim, V., Guvenc, I., Turan, V. and Karatas, A. (2007). Effect of foliar urea application on quality, growth, mineral uptake and yield of broccoli (Brassica oleracea L., var. italica). Plant, Soil and Environment, 53(3): 120-128.

\section{How to cite this article:}

Purabi Banerjee, Bishal Mukherjee, Ananya Ghosh, Madhushri Pramanik and Rajib Nath. 2020. Influence of Seed Priming and Foliar Nutrition on Quality and Nutrient Uptake of Relay Grass Pea (Lathyrus sativus L.) in Gangetic Plains of West Bengal. Int.J.Curr.Microbiol.App.Sci. 9(05): 2864-2872. doi: https://doi.org/10.20546/ijcmas.2020.905.329 